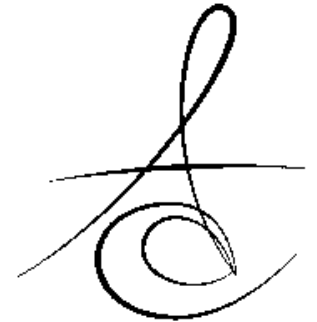

Makale Kodu/Article code: 3715

Makale Gönderilme tarihi; 01.06.2018

Kabul Tarihi: 17.10.2018

\section{AWARENESS AND USE OF CONE-BEAM COMPUTED TOMOGRAPHY (CBCT) OF TURKISH DENTIST}

\section{TÜRK DİŞ HEKİMLERİNİN KONİK IŞINLI BİLGİSAYARLI TOMOGRAFİ (KIBT) KULLANIMI VE FARKINDALIĞI}

\author{
Dr. Öğr. Üyesi Katibe Tuğçe TEMUR*
}

Dr. Öğr. Ömer HATİPOĞLU*

\section{ABSTRACT}

Aim: In this study, it was aimed to evaluate competence and awareness of dentists in Turkey with regard to use and application of cone-beam computerized tomography (CBCT).

Material and Methods: A questionnaire consisting of 12 questions was sent to approximately 2.000 dentists via electronic media. Feedback was received from 105 dentists. Completed questionnaires were examined and statistically analyzed using the results and chisquare test. Data analysis was performed using Statistical Package for the Social Sciences version 23.0 (SPSS Inc., Chicago, IL, USA).

Results: Of the dentists participating in the study, $91.4 \%$ reported they had CBCT awareness. In the study, $55.2 \%$ of dentists reported that they could interpret CBCT images. Of those who had knowledge about $\mathrm{CBCT}, 66.7 \%$ think that the training they get during undergraduate education is not enough. According to the study, CBCT was found to be used most commonly during implant planning (78.1\%). This was followed by cyst-tumor $(9.5 \%)$, orthodontic causes (1\%) and trauma (1\%).

Conclusion: Today, Turkish dentists have a high awareness of $\mathrm{CBCT}$. However, the interpret ability on $\mathrm{CBCT}$ images is not at the desired level. To meet the need for CBCT training of dentists in Turkey, hands-on training could be given at the universities along with theoretical lectures and practical courses rather than theoretical knowledge given by oral and maxillofacial radiology specialists after undergraduate education could be enhanced.

Keywords: Cone-Beam Computed Tomography, Education, Awareness, Dentist

\section{öz}

Amaç: Bu çalışmada, Türkiye'de diş hekimleri arasındaki konik ışınlı bilgisayarlı tomografinin (KIBT) kullanımına ve uygulanması yönelik yeterlilik ve farkındalıklarının değerlendirilmesi amaçlanmıştır.

Materyal ve metod: Elektronik ortamdan yaklaşık 2000 diş hekimlerine 12 adet sorudan oluşan anket gönderildi. Ancak 105 diş hekiminden geri bildirim alındı. Tamamlanan anketler incelendi, sonuçlar ve kikare testi kullanılarak istatistiksel olarak analiz edildi. Veri analizi, Statistical Package for the Social Sciences 23.0 versiyonu (SPSS Inc., Chicago, II., ABD) kullanılarak gerçekleştirildi.

Bulgular: Çalışmaya katılan diş hekimlerinin \%91,4 ünü KIBT farkındalığı olduğunu bildirdi. Çalışmada, diş hekimlerinin \%55,2'si KIBT görüntülerini yorumlayabileceklerini bildirdi. KIBT hakkında bilgi sahibi olan diş hekimlerin \%66,7 si lisans eğitiminde aldıkları eğitimin yeterli olmadığını düşünmektedir. Çalışmaya göre KIBT' $^{\prime}$ e en çok implant planlaması $(\% 78,1)$ sırasında başvurulduğu bulunmuştur. Bunu kist-tümör $(\% 9,5)$, ortodontik sebepler (\%1), travma (\%1) takip etti.

Sonuç: Günümüzde Türk diş hekimlerinin KIBT farkındalığı oldukça yüksektir. Ancak KIBT görüntülerinin yorumlanmasında ki yeterlilik istenilen seviyede değildir. Türkiye de diş hekimlerinin KIBT eğitimi ihtiyacına cevap vermek adına üniversitelerde teorik derslerin yanında, vaka üzerinde pratik derslere yer verilebileceği gibi lisans eğitimi sonrasında ağız diş ve çene radyolojisi uzmanları tarafından verilecek olan kurs ve seminerlerde teorik bilgiden çok kesitler üzerinde pratik eğitimler artırılabilir.

Anahtar Kelime: Konik Işınlı Bilgisayarlı Tomografi, Eğitim, Farkındalık, Diş hekimi

\footnotetext{
* Departmant of Oral and Maxillofacial Radiology, Sutcu Imam University, Kahramanmaraş
} 


\section{INTRODUCTION}

СВCT is a technique specially developed for dento-maxillofacial imaging. ${ }^{1}$ It is an extremely useful modality for evaluating high contrast structures, particularly bone. CBCT provides a number of avdantages in clinical practice when compared to conventional computed tomography (CCT). CBCT can be set to scan most specific small areas, as well as the entire craniofacial complex. In CBCT, the radiation dose is minimized by reducing the irradiated area. Since CBCT takes all the basic images in one rotation (10-70 seconds), the scan speed is rather fast. This reduces artifacts due to patient motion. In CBCT, the effective dose of radiation is reported to have decreased by $98 \%$ compared to CCT systems. CBCT provides spatial resolution under a millimeter, so images with high diagnostic quality can be obtained. ${ }^{2}$ However, there are some disadvantages of CBCTs. These include higher radiation doses compared to two-dimensional imaging methods; insufficient assessment of soft tissue lesions such as muscle, salivary gland, and other soft tissues; and limited correlation with Hounsfield units for standardizing bone density. ${ }^{3}$

CBCT is used in many areas in dentistry. Dentists mainly need $\mathrm{CBCT}$ for several reasons including planning of preoperative implant, evaluation lesions, evaluation of the relationship between the mandibular third molar root and the mandibular canal, localization of impacted teeth and assessment of their relation with anatomic structures (excluding the third molar), evaluation of TMJ pathologies, evaluation of paranasal sinus pathologies, evaluation of the traumatized patients in terms of fracture, evaluation of preoperative alveolar resorption and evaluation of cleft lip and palate. ${ }^{4,5}$

$\mathrm{CBCT}$ offers both dentists and other physicians who are involved with head-neck pathologies the opportunity to work with much better-quality images using much lower radiation doses when performed by taking into consideration ALARA (As Low As Reasonably Achievable) principle. ${ }^{6}$ Despite the increasing popularity of $\mathrm{CBCT}$, interpretation of acquired images is considered to require significant degree of expertise. ${ }^{7}$ However, questions such as proficiency in image interpretation with cone-beam computerized tomography and selection of the cases are on the agenda.
In this study, it was aimed to evaluate competence and awareness of dentists in Turkey with regard to use and application of $\mathrm{CBCT}$.

\section{MATERIALS AND METHODS}

In this study, a questionnaire consisting of 12 questions was sent to approximately 2.000 dentists through digital media. However, 108 dentists responded. Three questionnaires were excluded from the study because of the mistakes of the responders. One hundred and five questionnaires were included in the study. There were questions about dentists' demographic characteristics such as gender and age in one part of the questionnaire. In the other part, there were questions about CBCT awareness and use. The sample of the questionnaire is shown in Table-1. Completed questionnaires were examined, the results were assessed and statistically analyzed using chisquare test.

Data analysis was performed using the Statistical Package for the Social Sciences version 23.0 (SPSS Inc., Chicago, IL., USA). The probability level for statistical significance was determined as $p=0.05$.

Table 1. The survey form

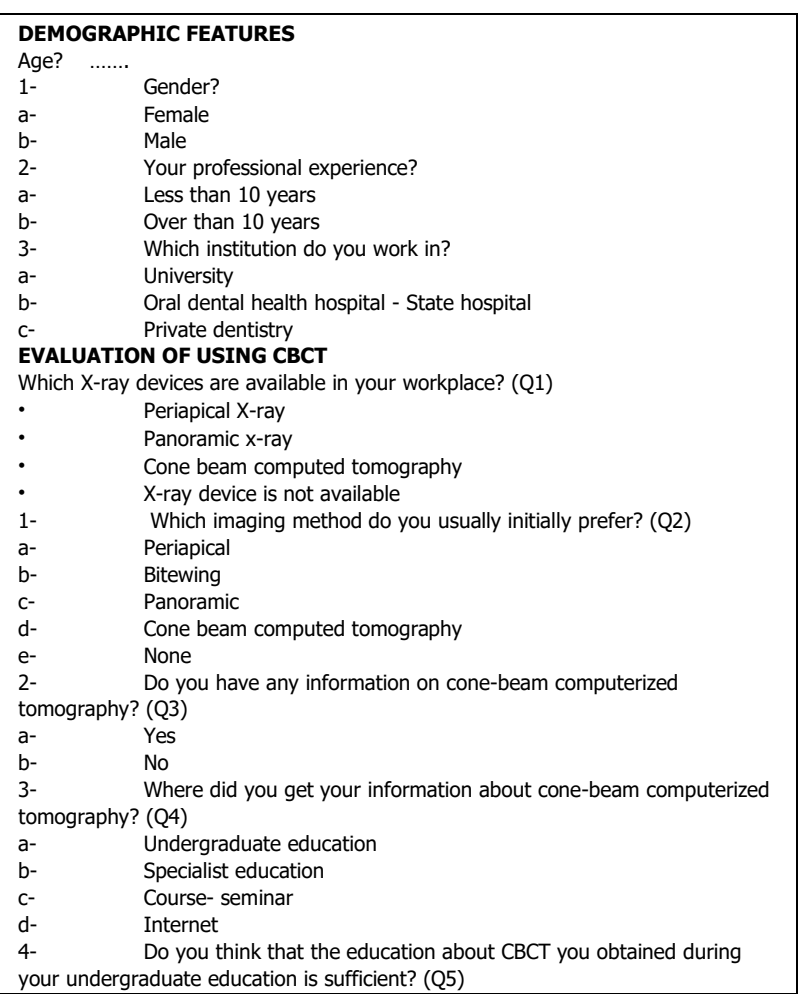




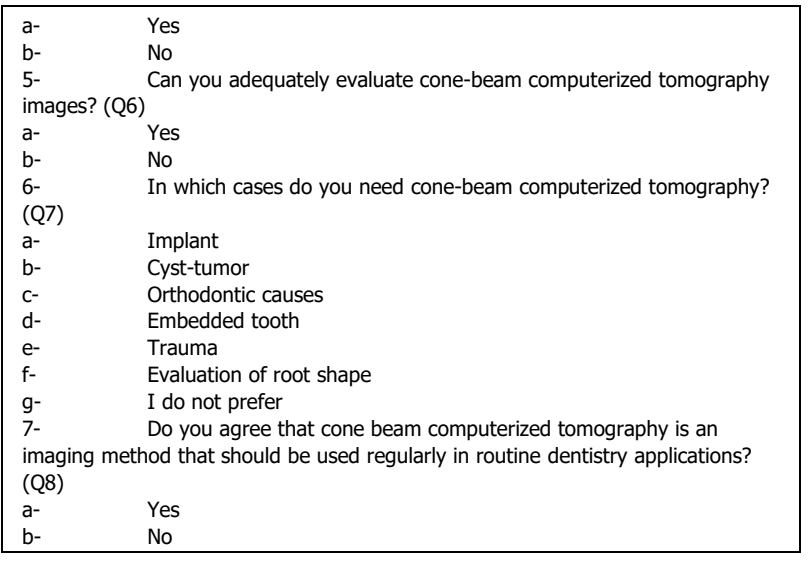

\section{RESULTS}

A total of 105 dentists were included in the study, 63 male and 42 female. The mean age of the participants is 32.28 years. The number of those with less than 10 years of professional experience is 32 and the number of those with more than 10 years of professional experience is 73 . It has been found that 55 of the dentists participating in the survey are working at private clinics, 21 at state hospitals and 29 at university hospitals (Table-2).

Table 2. Distribution of Turkish Dentists $(n=105)$ according to gender, experience, workplace

\begin{tabular}{|l|l|l|l|}
\hline Demographic features & Factors & $\mathbf{n}$ & $\mathbf{\%}$ \\
\hline \multirow{2}{*}{ Gender } & Male & 63 & 60 \\
\cline { 2 - 4 } & Female & 42 & 40 \\
\hline \multirow{3}{*}{ Experience } & $\leq 10$ Years & 32 & 69.5 \\
\cline { 2 - 4 } & $>10$ Years & 73 & 30.5 \\
\hline \multirow{2}{*}{ Workplace } & Private Clinics & 55 & 52.4 \\
\cline { 2 - 4 } & Public & 21 & 20 \\
\cline { 2 - 4 } & Universities & 29 & 27.6 \\
\hline
\end{tabular}

The first radiologic method performed by the participating dentists was the panoramic radiography (78.1\%). This was followed by periapical $\mathrm{x}$-ray $(21 \%)$ and bitewing x-ray.

The most common device available in private clinics was periapical X-rays $(81.8 \%)$. It was found that panoramic X-ray devices $(85.7 \%)$ were the most common devices in public hospitals. CBCT was most commonly found in the universities (89.7\%).

It was found that there was a significant difference between the institutions in which dentists worked and the first preferred imaging method ( $p$
<0.002) (Table-3). It is noteworthy that dentists first preferred panoramic radiography in all institutions. The number of dentists who preferred periapical $x$ rays in the first place was higher in private practices compared to other institutions.

On the other hand, $91.4 \%$ of the dentists participating in the study reported CBCT awareness. It was found that there was a significant difference between СВCT awareness and the institution of dentists $(p<0,019)$.

In the study, $55.2 \%$ of dentists reported that they could interpret CBCT images.

$66.7 \%$ of dentists who obtained knowledge about $\mathrm{CBCT}$ think that training in undergraduate education is not enough.

In this study, it was reported that CBCT information was obtained most frequently during undergraduate education (45.7\%), followed by course-seminars $(26.7 \%)$ and less commonly from internet (6.7\%).

It was found that there was a significant difference between the years of professional experience and source of knowledge obtained about CBCT $(p<0,001)$ (Table-3). It was noted that $61.9 \%$ of dentists who had less than 10 years of professional experience obtained knowledge about CBCT during undergraduate study. It was found that $62.5 \%$ of those who had more than 10 years of professional experience obtained knowledge about CBCT through courses.

According to the study, it was found that conebeam computerized tomography was most frequently used during implant planning (78.1\%). This was followed by cysts-tumors $(9.5 \%)$, orthodontic conditions (1\%) and trauma (1\%).

In private clinics, it was found that $90.9 \%$ of CBCT examinatons were performed for planning of implant. It was found in this study that eleven dentists were never in need of CBCT. It has been noted that six of these eleven dentists worked in state hospitals.

Finally, $63.8 \%$ of the dentists participating in the study reported that routine use of CBCT was not necessary. Percentage of Turkish dentists' answers according to gender, experience, workplace were tabled (Table 4). 
Table 3. Statistical data between the participants' demographic characteristics and the factors (Pearson's $\times 2$ tests).

\begin{tabular}{|c|c|c|c|}
\hline Factors & $\begin{array}{l}\text { Demographic } \\
\text { characteristics }\end{array}$ & $x^{2}$ & p-value \\
\hline \multirow[t]{4}{*}{ Q1 } & Gender & 0.148 & 0.7 \\
\hline & Experience & 4.184 & $0.041^{*}$ \\
\hline & Workplace & 10.838 & $0.004^{*}$ \\
\hline & Gender & 1.540 & 0.463 \\
\hline \multirow[t]{2}{*}{ Q2 } & Experience & 5.313 & 0.07 \\
\hline & Workplace & 16.586 & $0.002 *$ \\
\hline \multirow[t]{3}{*}{ Q3 } & Gender & 0.182 & 0.669 \\
\hline & Experience & 0.38 & 0.846 \\
\hline & Workplace & 7.875 & $0.019 *$ \\
\hline \multirow[t]{3}{*}{ Q4 } & Gender & 5.848 & 0.119 \\
\hline & Experience & 41.908 & $<0.001^{*}$ \\
\hline & Workplace & 34.174 & $<0.001^{*}$ \\
\hline \multirow[t]{3}{*}{ Q5 } & Gender & 6.169 & 0.226 \\
\hline & Experience & 0.982 & 0.301 \\
\hline & Workplace & 3.459 & 0.232 \\
\hline \multirow[t]{3}{*}{ Q6 } & Gender & 6.169 & 0.113 \\
\hline & Experience & 0.982 & 0.322 \\
\hline & Workplace & 3.459 & 0.177 \\
\hline \multirow[t]{3}{*}{ Q8 } & Gender & 0.247 & 0.619 \\
\hline & Experience & 0.486 & 0.485 \\
\hline & Workplace & 6.444 & $0.04 *$ \\
\hline
\end{tabular}

Table 4. Percentage of Responses of Turkısh Dentists according to gender, experience, workplace

\begin{tabular}{|c|c|c|c|c|c|c|c|c|}
\hline & & Male & Female & Public & Private & University & $<10$ Years & $>10$ Years \\
\hline \multirow{2}{*}{ Q1 } & CIBT & $17.4 \%$ & $11.9 \%$ & $33.3 \%$ & $16.4 \%$ & $89.7 \%$ & $20.6 \%$ & $7.1 \%$ \\
\cline { 2 - 9 } & Panoromic & $31.7 \%$ & $26.1 \%$ & $85.7 \%$ & $70.9 \%$ & $97.4 \%$ & $36.5 \%$ & $19 \%$ \\
\cline { 2 - 9 } & Periapical & $80.9 \%$ & $71.4 \%$ & $52.4 \%$ & $81.8 \%$ & $94.9 \%$ & $88.8 \%$ & $59.5 \%$ \\
\hline \multirow{2}{*}{ Q2 } & Bitewing & $0.0 \%$ & $2.4 \%$ & $4.8 \%$ & $0.0 \%$ & $0.0 \%$ & $1.4 \%$ & $0.0 \%$ \\
\cline { 2 - 9 } & Panoromic & $79.4 \%$ & $76.2 \%$ & $90.5 \%$ & $65.5 \%$ & $93.1 \%$ & $83.6 \%$ & $65.6 \%$ \\
\cline { 2 - 9 } & Periapical & $20.6 \%$ & $21.4 \%$ & $4.8 \%$ & $34.5 \%$ & $6.9 \%$ & $15.1 \%$ & $34.4 \%$ \\
\hline \multirow{2}{*}{ Q3 } & & $90.5 \%$ & $92.9 \%$ & $76.2 \%$ & $94.5 \%$ & $96.6 \%$ & $91.8 \%$ & $90.6 \%$ \\
\hline \multirow{2}{*}{ Q6 } & & $34.9 \%$ & $23.8 \%$ & $21.9 \%$ & $23.6 \%$ & $41.4 \%$ & $27.4 \%$ & $37.5 \%$ \\
\hline \multirow{4}{*}{ Q7 } & Implant & $74.1 \%$ & $40.5 \%$ & $38.1 \%$ & $61.8 \%$ & $55.2 \%$ & $52.1 \%$ & $62.5 \%$ \\
\cline { 2 - 9 } & Cist\&tumor & $71.4 \%$ & $71.4 \%$ & $61.9 \%$ & $72.7 \%$ & $75.9 \%$ & $71.2 \%$ & $71.9 \%$ \\
\cline { 2 - 9 } & Orthodontic & $22.2 \%$ & $11.9 \%$ & $19.0 \%$ & $20.0 \%$ & $13.8 \%$ & $16.4 \%$ & $21.9 \%$ \\
\hline & Embedded & $46.0 \%$ & $40.5 \%$ & $33.3 \%$ & $47.3 \%$ & $44.8 \%$ & $43.8 \%$ & $43.8 \%$ \\
\cline { 2 - 9 } & tooth & & & & & & & \\
\cline { 2 - 9 } & Trauma & $7.9 \%$ & $9.5 \%$ & $9.5 \%$ & $10.9 \%$ & $3.4 \%$ & $9.6 \%$ & $6.3 \%$ \\
\cline { 2 - 9 } & Pain & $0 \%$ & $0 \%$ & $0 \%$ & $0 \%$ & $0 \%$ & $0 \%$ & $0 \%$ \\
\cline { 2 - 9 } & Root-shaped & $1.6 \%$ & $0.0 \%$ & $0.0 \%$ & $0.0 \%$ & $1.8 \%$ & $0.0 \%$ & $3.1 \%$ \\
\cline { 2 - 9 } & I do not prefer & $9.5 \%$ & $11.9 \%$ & $28.6 \%$ & $5.5 \%$ & $6.9 \%$ & $9.6 \%$ & $12.5 \%$ \\
\hline \multirow{2}{*}{ Q8 } & & $38.1 \%$ & $33.3 \%$ & $14.3 \%$ & $45.5 \%$ & $34.5 \%$ & $38.4 \%$ & $31.3 \%$ \\
\hline
\end{tabular}




\section{DISCUSSION}

One of the new technological developments in modern dentistry is CBCT. The use of $\mathrm{CBCT}$ in dentistry is increasing rapidly due to its advantages such as exposure to lower radiation and lower cost compared to $\mathrm{CCT} .{ }^{7,8}$ Considering the recent evaluation of the study conducted by Farman et al., it has been reported that there are $3,000 \mathrm{CBCT}$ units in the USA and $800 \mathrm{CBCT}$ units in Germany. ${ }^{9}$ Despite the number of CBCT units in Turkey today is still relatively small, some recently opened dental schools along with oral and dental hospitals exhibit intention for obtaining CBCT device.

Most of the participants were male. However, no significant difference was found in the answers between male and female dentists.

The first preferred imaging method in all institutions in Turkey seems to be the panoramic radiographs. This can be explained by the fact that the panoramic x-ray can show an image of all the teeth on a single radiograph, thus providing an advantage for patients who are newly admitted to the clinic. Significant differences were found between the institution factor and the available x-ray machine in that institution. It has been observed that CBCT is more available in universities. This can be explained by the fact that the universities are both educational and referral institutions.

Dölekoğlu Dölekoğlu et al. ${ }^{10}$ reported that $56 \%$ of the dentists had general knowledge about $\mathrm{CBCT}$. In this study, answer to questions such as the CBCT awareness of dentists in Turkey, selection of cases for this imaging technique and competence level of interpreting the images obtained by CBCT was sought. An awareness of $\mathrm{CBCT}$ was reported by $91.4 \%$ of the dentists participating in the study.

In a study conducted in Sudan ${ }^{11}, \mathrm{CBCT}$ awareness was reported to be $77 \%$, while it was $42.5 \%$ in South India ${ }^{12}$ and $100 \%$ in Mangolare. ${ }^{13}$ Today, both practical and theoretical courses on CBCT are given in dento-maxillofacial radiology specialty in Turkey. During the undergraduate education however, theoretical courses on CBCT are more likely to be offered. Thus, awareness of dental CBCT in Turkey is very high. Besides, dento-maxillofacial radiology is a recognized specialty in countries such as Sweden and
Norway. Furthermore, in these countries, dentists were reported to have a tendency to wait for a radiology report before commencing treatment. ${ }^{14}$

In this study, $66.7 \%$ of dentists reported that the education they received during undergraduate education was inadequate. As a result of their study on Turkish dentists, Kamburoğlu et al. concluded that theoretical courses on СBCT education for undergraduate students were not sufficient and should be supported by practical training. ${ }^{15}$ Parallel to the work of Kamburoğlu et al., we think that it is not enough to give only $\mathrm{CBCT}$ education theoretically during undergraduate education and should be supported with practical lessons on case.

It was found that there was a significant difference between the duration of occupational experience and the place of obtaining knowledge about CBCT $(p<0,001)$. It has been reported that those with more than 10 years of professional experience have obtained CBCT related knowledge through courses and seminars while those with less than 10 years experience obtained this knowledge during their undergraduate education. This can be explained by the fact that dentistry faculties in Turkey follow technological developments and CBCT was added to the curriculum in recent years. On the other hand, Zain-Alabdeen et al. reported that dental surgeons learned more about CBCT through post graduate lectures in Saudi Arabia and Egypt and through seminars in Jordan. ${ }^{15}$ In this study, dentists in Turkey, despite the inadequate CBCT education at the graduate study finding, reported that more information on undergraduate education.

In the study, it was found that CBCT was most needed during implant planning. This was followed by cysts-tumors. Parallel with our study, some studies in literature reported that dental surgeons most commonly use CBCT during the implant planning phase. ${ }^{13-19}$ In 2000, the American Academy of Oral and Maxillofacial Radiology (AOMR) emphasized the importance of cross-sectional imaging in implant treatment planning, and it was reported that conventional tomography technique could be used to provide 3-D imaging. ${ }^{18}$ However, in the year 2012, AOMR issued a recommendation for the use of CBCT, which provides cross-sectional imaging and has advantages over $\mathrm{CCT} .{ }^{19}$ On the other hand, there are 
authors who recommend limiting the use of $\mathrm{CBCT}$ in specific postoperative complications, such as damage to neurovascular structures following placement of dental implants or postoperative infections associated with maxillary sinus. ${ }^{20}$

The use of cone-beam computerized tomography in the literature is suggested for cases where the clinical examination supported by conventional two-dimensional intraoral and extraoral x-ray cannot provide satisfactory diagnostic information. $^{21}$ Eleven dentists participating in the study reported that they did not need $\mathrm{CBCT}$. Of the dentists participating in this study, $63.8 \%$ reported that routine use of $\mathrm{CBCT}$ was not necessary. In parallel with the literature, this can be explained by the dental practitioner's view of the ALARA principle and the choice of imaging method according to the case.

\section{CONCLUSION}

To address the need for CBCT training of dentists in Turkey, practical courses along with theoretical lectures can be given in universities; furthermore, practical training rather than theoretical knowledge can be improved by courses and seminars given by oral and maxillofacial radiology specialists after undergraduate education. Furthermore, when dentists think they are inadequate to interpret tomographic images, an oral maxillofacial radiology specialist should request the report of the tomography image.

K.Tuğçe Temur: ORCID ID: 0000-0001-9947-5679 Ömer Hatipoğlu: ORCID ID: 0000-0002-4628-8551

\section{REFERENCES}

1. Angelopoulos C, Scarfe WC, Farman AG. A comparison of maxillofacial CBCT and medical CT. Atlas Oral and Maxillofacial Surg Clin North Am 2012; 20: 1-17.

2. Scarfe WC, Farman AG, Sukovic P. Clinical applications of cone-beam computed tomography in dental practice. J Canadian Dent Assoc 2006; 72: 75.
3. Benavides $\mathrm{E}$, Rios HF, Ganz SD, An CH, Resnik R, Reardon GT, et al. Use of cone beam computed tomography in implant dentistry: the International Congress of Oral Implantologists consensus report. Implant dentistry. 2012;21:78-86.

4. Akarslan Z, Peker İ. Reasons of cone-beam computed tomography examination requests in a dental faculty. Acta Odontologica Turcica 2015;32:1-6.

5. Cakur B, Sümbüllü MA, Durna D, Canakcı CF. Dental volumetric computed tomography in the radiological detection of dento-alveolar fracture. J Dent Fac Atatürk Uni 2012;22:57-60.

6. Evlice BK, Oztunç $H$. Digital radiography and advanced imaging techniques in dentistry. Arch Med Review J 2013;22:230-8.

7. Ahmed F, Brooks SL, Kapila SD. Efficacy of identifying maxillofacial lesions in cone-beam computed tomographs by orthodontists and orthodontic residents with third-party software. Am J Orthod Dentofac Orthop 2012;141:451-9.

8. Ludlow JB, Davies-Ludlow L, Brooks S, Howerton W. Dosimetry of $3 \mathrm{CBCT}$ devices for oral and maxillofacial radiology: CB Mercuray, NewTom 3G and i-CAT. Dentomaxillofac Radiol 2006;35:219-26.

9. Farman AG. Guest Editorial-Self-referral: an ethical concern with respect to multidimensional imaging in dentistry? J Appl Oral Sci 2009;17:1678-7757.

10. Dolekoglu S, Fisekcioglu E, Ilguy M, Ilguy D. The usage of digital radiography and cone beam computed tomography among Turkish dentists. Dentomaxillofac Radiol 2011;40: 379-84.

11. Eltayeb AS, Satti A, Ahmad AG. Knowledge and Attitudes of Dentists towards Cone Beam Computed Tomography in Khartoum. Sudan 2017; 7: 32-5.

12. Reddy RS, Kiran CS, Ramesh T, Kumar BN, Naik RM, Ramya K. Knowledge and attitude of dental fraternity towards cone beam computed tomography in south India-A questionnaire study. Indian J Dent 2013;4:88-94.

13. Shetty S, Castelino R, Babu S, Laxmana A, Roopashri K. Knowledge and attitude of dentists towards cone beam computed tomography in mangalore-a questionnaire survey. Austin J Radiol 2015; 2: 1016. 
14. Strindberg JE, Hol C, Torgersen G, Møystad A, Nilsson $M$, Näsström $K$, et al. Comparison of Swedish and Norwegian use of cone-beam computed tomography: a questionnaire study. J Oral \& Maxillofac Res 2015;6:2.

15. Kamburoğlu K, Kurşun Ş, Akarslan Z. Dental students' knowledge and attitudes towards cone beam computed tomography in Turkey. Dentomaxillofac Radiol 2011;40:439-43.

16. Zain-Alabdeen EH, El Khateeb SM. Comparison of knowledge and perspectives toward cone-beam computed tomography among dentists in three Middle East regions: A cross-sectional study. Saudi J Oral Sci 2018;5:3.

17. Arnheiter C, Scarfe WC, Farman AG. Trends in maxillofacial cone-beam computed tomography usage. Oral Radiol 2006; 22:80-5.

18. Tyndall DA, Brooks SL. Selection criteria for dental implant site imaging: a position paper of the American Academy of Oral and Maxillofacial Radiology. Oral Surg Oral Med Oral Pathol Oral Radiol Endod 2000;89:630-7.

19.Tyndall DA, Price JB, Tetradis S, Ganz SD, Hildebolt C, Scarfe WC. Position statement of the American Academy of Oral and Maxillofacial Radiology on selection criteria for the use of radiology in dental implantology with emphasis on cone beam computed tomography. Oral Surg Oral Med Oral Pathol Oral Radiol 2012;113:817-26.

20. Bornstein MM, Horner K, Jacobs R. Use of cone beam computed tomography in implant dentistry: current concepts, indications and limitations for clinical practice and research. Periodontol 2000 2017;73:51-72.

21. Dula K, Bornstein MM, Buser D, Dagassan-Berndt $D$, Ettlin DA, Filippi A, et al. SADMFR guidelines for the use of Cone-Beam Computed Tomography/ Digital Volume Tomography. Swiss Dent J 2014; 124: $1169-83$.

\section{Yazışma Adresi}

Katibe Tugce Temur

Departmant of Oral and Maxillofacial Radiology

Sutcu Imam University,

Kahramanmaras, Turkey.

E-mail address: tugcetemur@ksu.edu.tr

Phone: +903443003885 